九州大学学術情報リポジトリ

Kyushu University Institutional Repository

\title{
A Comparison Study of Heap Bioleaching Sites in Chile and Finland for Further Development of Biotechnology for Mining
}

Tanaka, Masahito

Graduate School of Engineering, Kyushu University

https://doi.org/10.5109/1929724

出版情報 : Evergreen. 4 (4)，pp.1-7，2017-12. Green Asia Education Center バージョン：

権利関係 : 


\title{
A Comparison Study of Heap Bioleaching Sites in Chile and Finland for Further Development of Biotechnology for Mining
}

\author{
Masahito Tanaka* \\ Graduate School of Engineering, Kyushu University, Japan \\ *Author to whom correspondence should be addressed, \\ E-mail: m-tanaka13@mine.kyushu-u.ac.jp
}

(Received August 7, 2017; accepted October 16, 2017).

\begin{abstract}
For sustainable metal resources development, the installation of environmentally-friendly biotechnology into mining industry plays an important role. In order to search for the factors affected on biotechnology installation, this study compared and investigated several factors in heap bioleaching sites in Chile and Finland. Both cases were financially supported by foreign capitals through the mining projects regardless of the political economic scale. The business strategies of mining operators strongly affect the selection of latest technologies installation in Chile. Additionally, environmental perspective possibly affected as well as profitable technology in the Finland case. Therefore, heap bioleaching are developed and selected in mining industry.
\end{abstract}

Keywords: bioleaching, mining, economic scale, environmentally-friendly development.

\section{Introduction}

Recent economic development in developing countries and resource nationalism increase the demand for resources such as copper, gold, silver, nickel, and so on. Consequently, while high-grade surface mineral deposits have been worked out, low-grade deep metal ores such as chalcopyrite $\left(\mathrm{CuFeS}_{2}\right)$, gold-bearing pyrite $\left(\mathrm{FeS}_{2}\right)$, and impurities-containing metal ore (enargite; $\mathrm{Cu}_{3} \mathrm{AsS}_{4}$, tennantite; $\mathrm{Cu}_{12} \mathrm{As}_{4} \mathrm{~S}_{13}$, gold-bearing arsenopyrite; FeAsS, etc.) came to be utilized. These low grade ores are usually processed by hydrometallurgical metal recovery process rather than pyrometallurgical one in economically viable aspect. As one of the hydrometallurgical process, microbiological techniques such as bioleaching (extraction of metals from low-grade metal ores via microbial Fe(II)- and sulfur-oxidation) and biooxidation (a pre-treatment technique for refractory gold ores prior to chemical cyanide leaching using the same mechanism of bioleaching) have been developed in mining area (Fig. 1). The economic advantages of microbial process in extraction of metals from low-grade deposits are summarized as follows: (i) copper have been recovered from low-grade ores and dumps which have been left behind from previous mining operations, (ii) bioleaching is considered as more environmentallyfriendly process than conventional physical-chemical techniques (roasting and smelting) due to lower energy consumption, no sulfur dioxide $\left(\mathrm{SO}_{2}\right)$ gas emission ${ }^{1)}$ and no biowastes, (iii) tailings from biomining (e.g. bioleaching and biooxidation) operations are less chemically active and the biological activity is reduced by the extent to which they have already been leached, whereas mine tailings and wastes produced from physico-chemical process might produce unwanted acid and metal pollution ${ }^{1)}$. Biological techniques have advantages in low cost and low environmental impact ${ }^{2-5)}$. Therefore, application of biotechnology for mining and environmental remediation is one of the countermeasures for sustainable development.

Heap bioleaching is the technique for extraction of metals such as copper, iron, zinc, nickel and cobalt. Low-grade mineral ore is mined, followed by several mineral processing. The concentrates is piled onto the impermeable base and a heap is built with a size of width $2400 \mathrm{~m} \times$ depth $800 \mathrm{~m} \times$ height $15 \mathrm{~m}$ as an example ${ }^{6)}$. From the top of the heap, acidic leach solution such as dilute sulfuric acid $\left(\mathrm{H}_{2} \mathrm{SO}_{4}\right)$ is supplied and percolated through the crushed ore. Inside of the heap, the growth of microorganisms and microbial iron- and sulfur-oxidation activity result in the dissolution of minerals and solubilization of metals with passive aeration or active air blown through pipes installed at the bottom of the heap. The metal-bearing leach solutions are regularly collected and sent to electrowinning process (Fig. 2). As a result, high-grade metals are recovered. The solvent is reused as acidic leach solution and the metal extraction cycle is proceeded. In case of gold and silver ores, these processes are also utilized as pre-treatment (biooxidation) prior to chemical cyanide leaching. Heap leaching has advantages including simple equipment, low capital and operation cost, and reasonable yields over a period of recirculation ${ }^{4}$. The capital cost of heap bioleaching depends on the ore grade and total cash cost 
was calculated as 109.6 US\$/ton for ore grade of $0.4 \%$, $64.9 \mathrm{US} \$ /$ ton for $1.2 \%$, which accounts for $50 \%$ of conventional smelting or refining operation cases $^{7}$. Annual operation cost is also within the range of 67-135 US\$/ton Cu in case of several bioleaching projects such as Collahausi, Chuquicamata and Salvador ${ }^{7)}$. Therefore, bioleaching can be applied even for low grade ore, while copper price is $5000-7000$ US\$/ton. In contrast, it is disadvantageous in that (i) it takes longer time to get the production into full swing (less profits), since microbial leaching is slower reaction than conventional smelting, (ii) although bioleaching is definitely environmentallyfriendly compared to conventional processes, toxic chemicals (e.g. arsenic, chromium) are leached and it possibly leads the inhibition of bacterial activities and environmental pollution, (iii) once the operation is started, bioleaching reaction cannot be stopped immediately. Nonetheless, since bioleaching makes it possible to produce the valuable metals from the low-grade ores which are so far disposed, copper heap bioleaching operations have been commissioned in the world such as Chile, Peru, Australia, and the US ${ }^{1-2)}$.

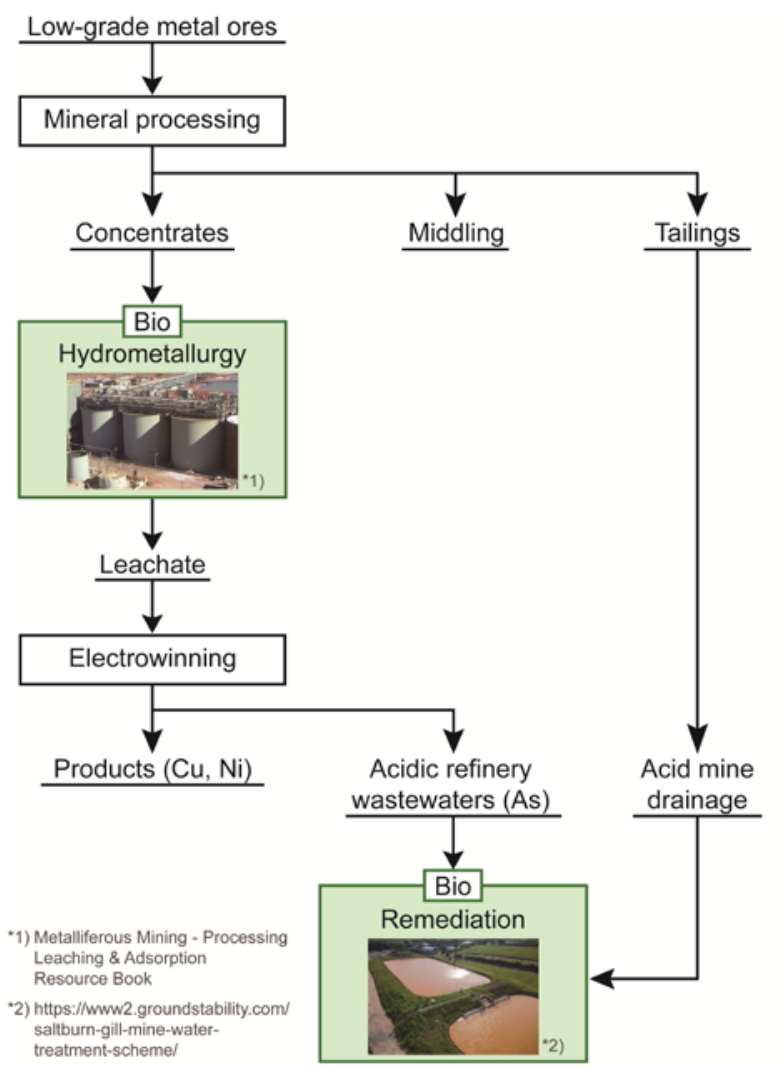

Fig. 1: Process flow chart of metal production from low-grade ores and the applicable area of biological techniques.
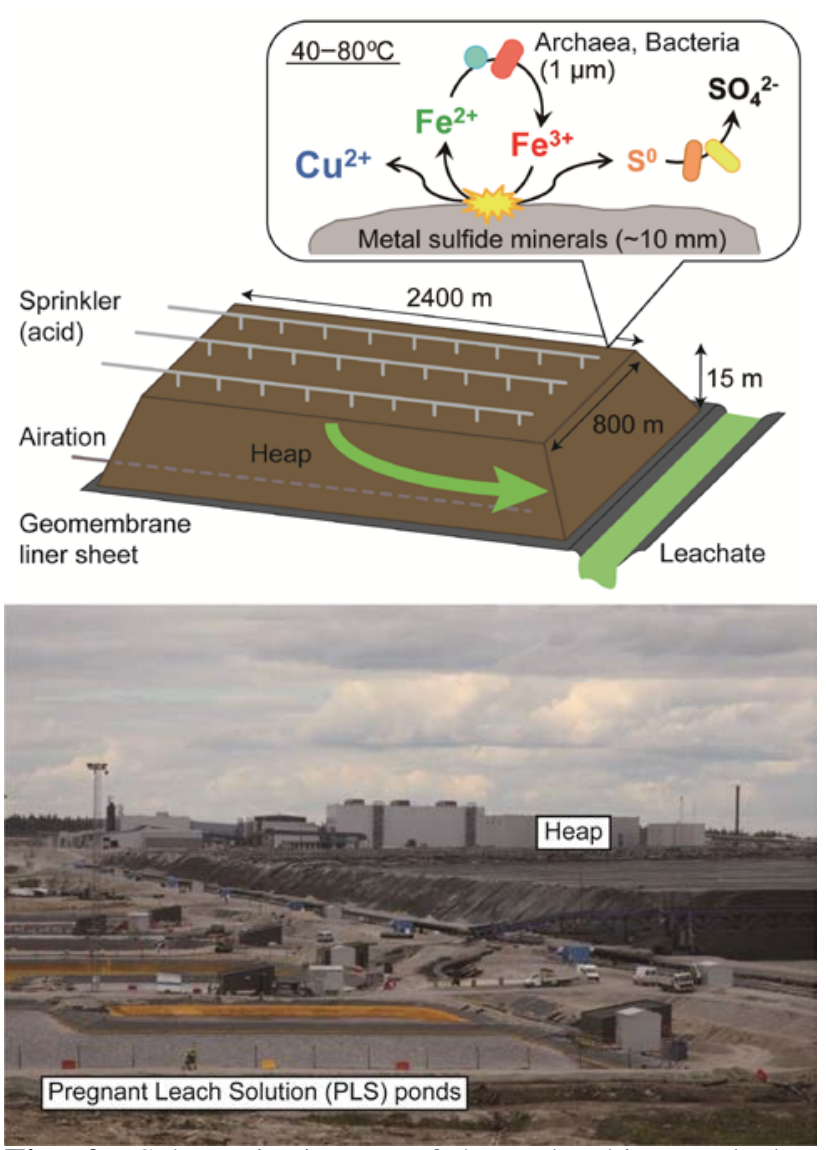

Fig. 2: Schematic image of heap leaching and the mechanism of indirect bioleaching (top). Bio-heap and pregnant leach solution (PLS) ponds in Talvivaara mine, Finland (modified) ${ }^{9)}$ (bottom).

Biotechnology is applicable to hydrometallurgy and the "biohydrometallurgy" is one of the most successful and commercially enlarged biotechnology fields in the world. The leachate is applied to electrowinning process for high grade metals production. As a byproduct, acidic refinery wastewaters are produced and it contains highly toxic impurities such as arsenic with the dissolution of arsenic-bearing metal ores such as enargite and arsenopyrite. For treatment of these toxic materials, biotechnology is also applicable in remediation process (Fig. 1). Passive treatment systems are widely constructed for heavy metal removal from acid mine drainage (AMD) generated from tailings and abandoned mines $^{8)}$. However, these biological remediation techniques for high concentration toxic materials removal have not been installed in actual operation yet.

For sustainable metal resources development in the world, the installation of biotechnology into mining industry will play an important role. In order to search for the factors affected on biotechnology installation, this study aimed to investigate and compare several factors in actual heap bioleaching sites in Chile and Finland. These two countries produce metals such as copper, nickel, gold, and minor metals (Fig. 3), and some of these major mines (e.g. Chuquicamata, Escondida and Talvivaara) 
are developed by heap bioleaching. Chile is one of the leading producers of bioleached copper in the world, and bioleaching operation accounts for approximately $10 \%$ of Chilean copper production. On the other hand, the largest nickel mine in Europe, Talvivaara mine located in Finland adopts bioleaching techniques. This mine is considered as a model bioleaching plant in Europe and well researched. The economic scale of Chile (developing country) is smaller than that of Finland (developed country). Nevertheless, both countries successfully installed the heap leaching systems. It is supposed that not only technical aspects but also other factors possibly affected the construction of heap leaching sites. Bioleaching has been researched for a long period from the 1950s and the number of commercial bioleaching sites has gradually increased over the last several decades in the world. Since bioleaching is considered as the economic and environmentally-friendly technology, these aspects can be the key factors for successful installation of the novel biotechnology. Therefore, the processes of heap bioleaching installation were compared from the view point of historical background, economic and environmental aspects in this study.

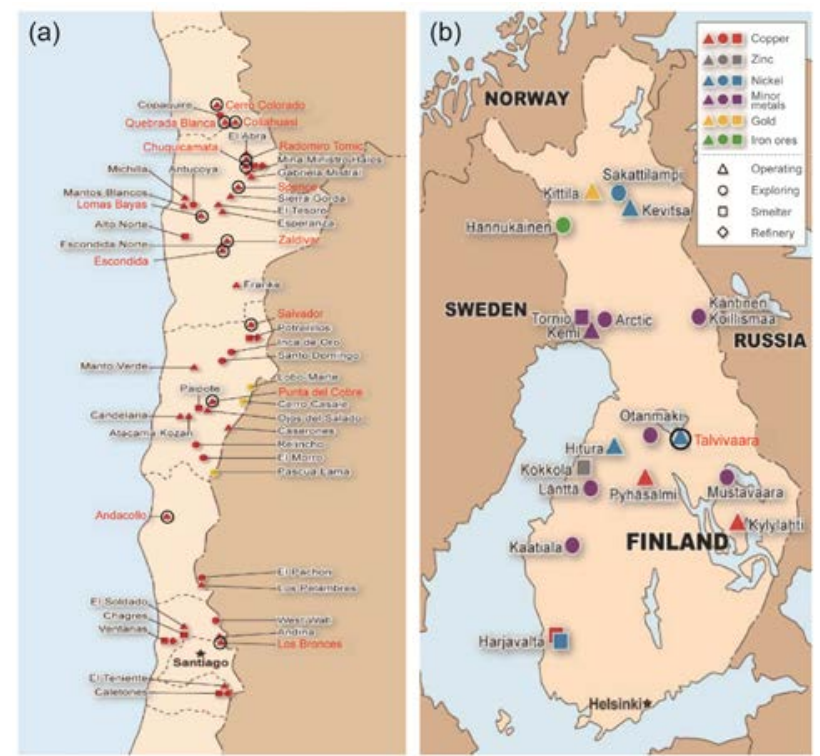

Fig. 3: Location of major metal mines in Chile (a) and Finland (b) (modified) ${ }^{10,11)}$. Marked minesites (०) indicate the commercial bioleaching plants.

\section{Chile}

\subsection{Mining industry in Chile}

Chile is the primary producer of copper in the world ${ }^{12)}$ from the beginning of the 20th century with great varieties of technological application of copper. Chile produces approximately $30 \%$ of world's copper production $^{13)}$. Its economic background is strongly based on copper production; $12 \%$ of real GDP is came from mining industry and over the half of exports are mineral products $(54 \% \text { in } 2015)^{14)}$. Major market partners are
China, US, Japan and India ${ }^{15)}$. Chilean copper mines are classified as Codelco Chile (Corporación Nacional del Cobre de Chile) which is Chilean state owned copper mining company such as Chuquicamata El Teniente and Radomiro Tomic mine, or private company such as Escondida, Collahuasi. Codelco was established in 1976 to acquire copper resource interests which were dominated by foreign capitals especially US ${ }^{16)}$. Reserved copper in Chile is 210 million metric tons, and it accounts for $29 \%$ of the whole amount of copper reserves (720 million metric tons) in 2016 ${ }^{17)}$. Therefore, sustainable copper resource production is required for Chilean economic development. However, mining in Chile faces to several problems as follows; (1) downturn of the new development the number of mines, (2) production cost increase due to the deep part of the quality deterioration-mining area of the ore, (3) increase in equipment and labor costs, (4) power energy costs, (5) the difficulty of industrial groundwater ensure ${ }^{18)}$. For continuous economic development, Codelco and private companies have been required to find a solution to these problems.

\subsection{Historical background of bioleaching development in Chile}

Chile is one of the leading countries of bioleaching operation in the world. Major heap bioleaching sites in Chile include Quebrada Blanca, Escondida, Radomiro Tomic, Zaldivar, Collahuasi, Chuquicamata, and so on ${ }^{5}$. Historical background of bioleaching development in Chile was summarized by Gentina and Aceedo (2013, 2016). In the late 1960s, Chilean government established two research institutes; CIMM (Centro de Investigaciones Minero Metalurgicas; Mining and Metallurgical Research Center) and INTEC (Instituto de Investigaciones Tecnologicas; Technological Research Institute). CIMM was joint project with United Nations Development Programme (UNDP) and started bioleaching in Potrerillos mine in the early 1970s. INTEC also started the research of bioleaching. The research has received significant scientific and economic support from international projects as follows: Metallurgical Technology-Copper (1979-1981), Research and Development of Metallurgical ProcessesHydrometallurgy (1982-1985), and Biotechnology Applied to Copper Mining (1985-1988) from Organization of American States (OAS). In the 1980s, Chile set up the application of biotechnology to copper mining as the important policy for country economy and development. This project received financial support from Chilean government and UNDP. From these research results, several large-scale bioleaching operations were started in Chile such as Lince-Michilla mine, Quebrada Blanca, and Cerro Colorado in the $1990 \mathrm{~s}^{13,18)}$. The hydrometallurgical techniques has been innovated depending on the metal price, and proceeded at the point of low metal price ${ }^{19)}$. This trend was also 
satisfied in case of Chile. Especially, large financial supports for bioleaching technology development were supplied during long-term copper price decrease in 1980-1990. From these historical backgrounds, bioleaching technologies have been developed by critical situation of copper ore degradation and supporting from foreign investments.

\subsection{Mining operator in Chile}

Major heap bioleaching sites in Chile are operated by not only Codelco (Chuquicamata, Radomiro Tomic), but also BHP Billiton (Cerro Colorado, Spence, Escondida), Xtrata (Collahuasi), Anglo American (Los Bronces), Vale (Tres Valles), Barrick (Zaldivar), and so on ${ }^{5}$. The operators mainly consist of major international mineral resources companies (five metal resources major; BHP Billiton, Rio Tinto, Anglo American, Vale, Glencore) which are not defined clearly, but it is adopted by satisfying the following conditions; (1) developing the business internationally to produce multiple mineral species (iron and non-ferrous minerals), and (2) standing high in the world production of these mineral resources ${ }^{10)}$. Others are also recognized as international large-scale enterprises in metal resources field. This indicates that Chilean mining industry is developed by foreign capitals to obtain copper resources and benefits stably. Development of copper mine takes high cost and time for approximately 10 years started from exploration of ore deposits, boring survey, feasibility study, plant construction, and operation. Additionally, bioleaching application also requires a long period for full operation and minute researches. Therefore, large funding is necessary for bioleaching development. Since these companies operate many mining sites throughout the world, bioleaching are possibly installed continuously in Chile.

As an example of new entry into bioleaching in Chile, Japanese mining company, JX Nippon Mining \& Metals Corporation and Chilean state-owned copper mining company, Codelco collaborated and established the biomining development company, BioSigma S.A. in Chile ${ }^{20)}$. The company focused on creating new technologies for isolation, growth, and monitoring the biomining microorganisms. In 2014, Codelco decided to install the biomining technologies developed by BioSigma for commercial production to Radomiro Tomic mine. Pilot trials were also conducted at Codelco's other copper mines; El Teniente and Chuquicamata mine. However, JX Nippon Mining \& Metals transferred all BioSigma shares to Codelco in October 2016 because there was little prospect of its application in JX Nippon Mining \& Metals' mines in future ${ }^{21)}$. As a result, BioSigma became a wholly owned subsidiary of Codelco. The bioleaching technologies developed in BioSigma is applied only to Codelco-owned copper mines. This Japanese company was a forerunner in heap bioleaching, and they operate a few copper mines in Chile. This background may lead to withdraw from bioleaching development.

\section{Finland}

\subsection{Mining industry in Finland}

Finland is one of the developed countries with higher GDP per capita (42,268 US\$ in 2015) than that of Chile $(23,211 \text { US\$ in 2015) })^{22)}$. Finnish major industry consists of paper and pulp, metal, machinery, information and communications and electronic equipment. Mining and quarrying industry accounts for only $0.3 \%$ of total GDP in 2015 23), while Chile depends on copper production. Finnish major business partners who require copper, nickel, and zinc are Germany, Netherland, and United States ${ }^{11)}$. However, when viewed from the perspective of European high-tech industry, mining in Finland is strongly important, since various metals such as nickel, cobalt and gold in addition to base metals are produced and the largest-scale lithium deposits in Europe were observed $^{11)}$.

\subsection{Historical background of bioleaching development in Finland}

Bioleaching technology has been developed in Europe countries, and then primary commercial bioleaching has been installed in Talvivaara mine in Finland (Fig. 3), which is one of the biggest nickel, cobalt and copper mine. Anticipated metal productions are as follows; nickel 33,000 tonnes/year, zinc 60,000 tonnes/year, copper 10,000 tonnes/year, and cobalt 1,200 tonnes/year. The ownership is possessed by Talvivaara Mining Company (80\%) and Outokumpu (20\%) ${ }^{24)}$. Development of Talvivaara mine was as follows. This ore deposits were found in the 1980s. Since the grade is too low to mine by conventional hydromeltallurgical techniques, application of bioleaching was considered ${ }^{25)}$. Talvivaara mine aims to be a pioneer in the mining industry. On Talvivaara mine website ${ }^{26}$, they show that Talvivaara mine has the opportunity to develop responsible best practices and to introduce environmentally efficient technology. Installing these bioleaching technologies in mining development may be one of the company policies of Talvivaara mine. In fact, bioleaching for this mine were researched and developed by financial supports such as Tekas; National Technology Agency of Finland from 1987, commencement of Talvivaara Project in 2004, and collaborating research with Tampere, Helsinki and Lappeenranta Universities of Technology and OMG Kokkola Chemicals $\operatorname{Ltd}^{9,25)}$. In 2005, 110 ton Pilot scale leaching trial as Bioshale project sponsored by European Union and 17,000 ton demonstration plant was constructed in May and started initial operation in August ${ }^{27}$.

\subsection{Bioshale project}

In order to develop the cleaner, safer and more 
environmentally-friendly production method for mining, bioshale project has been started since 2004-200728,29). This project was co-funded by the European Commission in the Six Framework Programme for Research and Development. Bioshale project aimed to produce base metals (copper, nickel, zinc, cobalt) and precious metals (gold, silver, palladium, platinum) from black shales ores which widely presence in Europe countries ${ }^{29)}$. To achieve the development of innovative biological processes for environmentally-friendly black shale ore mining, it consisted of six work packages: WP1 Resources assessment, WP2 Black shale ore preparation, WP3 Bioprocessing, WP4 Hydrometallurgy, WP5 Process product characterization, and WP6 Synthesis, which were leaded by research institute, company, and universities in Finland, Poland, United Kingdom, Spain and France in each work package, and supported by those in Germany, Bulgaria and Czech Republic in Research and Development activities (Fig. 4). Produced base and precious metals mainly consumed by European countries. Although mining sector accounts for lower proportion in Finland's GDP than that in Chile, it is inevitable that significantly affect the Finnish economy if the metal production is reduced. Therefore, it is expected that mining companies in Finland have introduced bioleaching technology with a will of their own. As well as mining situation in Chile, withstanding low profits of bioleaching and minute researches for stable operation are required. Additionally, this project focused on environmental protection for sustainable mining development. This project possibly supported to develop environmentally-friendly bioleaching technology in Finland.

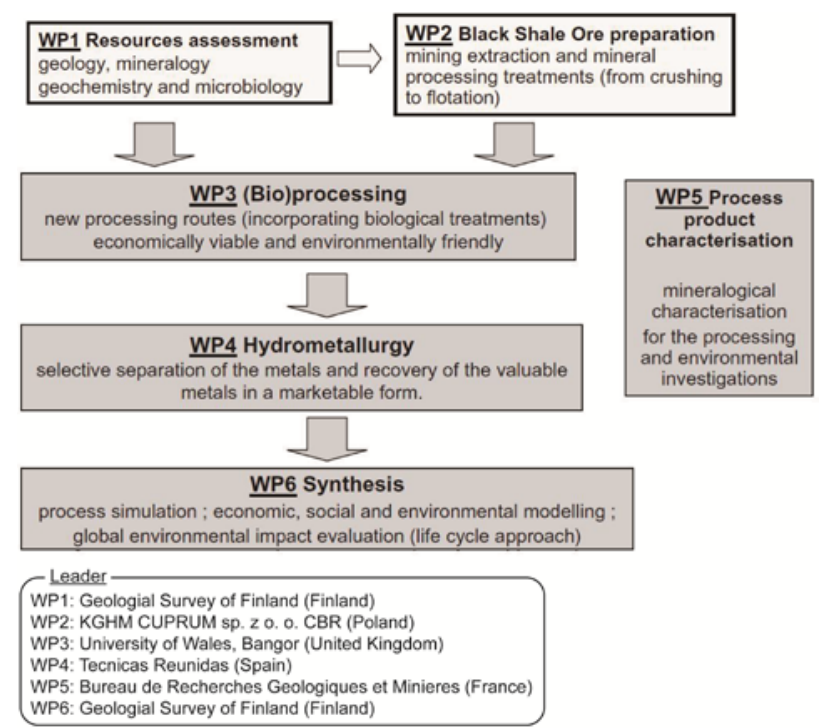

Fig. 4: Bioshale project structure (modified) ${ }^{29)}$.

\subsection{Mining strategy in Finland}

In terms of mining policy trend in Finland, JOGMEC report (2016) listed as following three topics. Natural resources strategy was published in 2010, and three objectives were prioritized: (i) promotion of domestic growth, (ii) problem-solving of the global mineral resource procurement, (iii) environmental impact measures. In addition, four plans of action were listed; (a) strengthening of the mineral resources policy, (b) securing raw materials supply, (c) reduction of the environmental impact and improvement of productivity, (d) strengthening of research \& development and expertise. On the other aspects, environmental protection act was revised on September 2014. It promotes the introduction of the latest technology in industrial activity facilities in factory. These revisions have possibility to install the new technology such as bioleaching in mining. Third topic is investment support from Finnish state. Finnish state established the state-owned industrial investment company, Finnish Industry Investment Ltd (FII), and they continue to invest to mining development ${ }^{11)}$. Investment is one of the important factors in mining development and installing new technology. Therefore, this support possibly promotes the bioleaching development. The common strategy depends on environmental protection. Europe has focused on environmental issues, and it is considered to be active also in the introduction of biotechnology which is low environmental impact. For this reason, it is expected that awareness of the national environment is one of the major factors for prompting the bioleaching techniques introduction in Finland.

\section{Comparison of Chilean and Finnish situation of bioleaching application}

These two countries were compared and different items were summarized in Table 1 . Chilean economy strongly depends on copper mining industry, and it is mainly developed by foreign companies such as major international mineral resources companies (BHP Billiton, Anglo American, Vales) and state-owned company, Codelco. Heap bioleaching in Chile was installed depending on these companies' business strategies. These companies have wide experiences in mining operation in the world, and stably obtain large benefits. For heap leaching system construction, large funding is required because of long preparation period over 10 years. Therefore, bioleaching technologies are installed continuously in developing country, Chile.

In contrast, mining industry in Finland accounts for only the small amount of total GDP, while Chile depends on copper production. The metal resources produced in Finland are mainly exported to European countries for high-tech industry. Finnish bioleaching technologies were developed as Bioshale project sponsored by the European Commission as the Six Framework Programme for Research and Development. This policy aimed to define the novel mining techniques for environmentally-friendly development together with high economic performance. Additionally, the mining policy and environmental protection act in Finland were 
Table 1: Comparison of key factors for application of bioleaching in Chile and Finland.

\begin{tabular}{lllllll}
\hline & GDP & $\begin{array}{l}\text { Mining sectors } \\
\text { importance }\end{array}$ & $\begin{array}{l}\text { Company } \\
\text { scale }\end{array}$ & State policy & $\begin{array}{l}\text { Involvement } \\
\text { from Japanese } \\
\text { company }\end{array}$ & Operator \\
\hline Chile & Developing & Significant & Large & Economic & Past & Domestic + overseas \\
Finland & Developed & Minor & Small & Environment & None & Domestic company \\
\hline
\end{tabular}

revised in 2010 and 2014, respectively to intensify the environmental measures in Finnish industry. These revisions have possibility to install the new technology such as bioleaching in mining.

\section{Conclusions}

In this paper, I compared heap bioleaching sites in Chile and Finland in terms of historical background, economic and environmental points. Although Chile and Finland are different economic scale, both countries were financially supported by foreign capitals through the mining development projects in the 1970s-1990s. Developing Chilean economy strongly depends on copper mining industry, and major operators consist of domestic and foreign companies such as major international mineral resources companies which have wide experiences in mining operation in the world and stably obtain large benefits. This indicates these companies' business strategies affect the application of bioleaching. In case of Finland, mining industry accounts for only the small amount of total GDP. Finnish bioleaching technologies were developed by the support from European Commission's project which aimed to define the novel mining techniques for environmentally-friendly development together with high economic performance. The mining policy and environmental protection act in Finland were revised in 2010 and 2014 to intensify the environmental measures in Finnish industry. These revisions possibility lead to install the new technology such as bioleaching in mining.

In order to install bioleaching system, withstanding low profits and minute researches for stable operation are required regardless of the political economic scale. The business strategies of mining operators strongly affect the selection of latest technologies installation, especially in developing countries. In developed countries, environmental perspective also possibly affected as well as profitable technology. Therefore, environmentally-friendly heap bioleaching technologies are developed and selected in mining industry.

For further commercialization of bioleaching techniques in the society, it is considered that reliable knowledge (e.g. applicable range, microbial control, wastewater management) is required. The trend of mining strategy in the world earns to acquire the higher interest in the mine due to securing of profit and stable metal supply. Actually, Japanese mining companies own little minesites and failed to install bioleaching. Recent mining industry has to produce metals from low-grade ore deposits and there are some cases that Japanese companies abandoned the mine development due to extremely poor ore grade. For stable metal supply and profit securement, these companies should conduct research on bioleaching continuously to handle the various mine scale.

\section{Acknowledgement}

The author is grateful for financial assistance provided by the Kyushu University Advanced Graduate Program in Global Strategy for Green Asia.

\section{References}

1) D.E. Rawlings, D. Dew, and C.K. du Plessis, TRENDS in Biotechnology, 21, 38 (2003).

2) J.A. Brierley and C.L. Brierley, Hydrometallurgy, 59, 233 (2001).

3) F. Acevedo, Electronic Journal of Biotechnology, 5, 18 (2002)

4) N. Pradhan, K.C. Nathsarma, K. Srinivasa Rao, L.B Sukla, and B.K. Mishra, Minerals Engineering, 21, 355 (2008).

5) S. Panda, A. Akcil, N. Pradhan and H. Deveci, Bioresource Technology, 196, 694 (2015).

6) K. Sasaki and C. Tokoro, Journal of MMIJ, 127, 724 (2011).

7) H. William, Producing Copper Nature's Way: Bioleaching (2004), available at https://www.copper.org/publications/newsletters/inn ovations/2004/05/producing_copper_natures_way_ bioleaching.html.

8) J. Skousen and P. Ziemkiewicz, Proceedings American Society of Mining and Reclamation, Breckenridge CO, 1100 (2006).

9) M. Riekkola-Vanhanen, Nova Biotechnol., 10, 7 (2010).

10) JOGMEC, Trends in the world of mining 2016: Chile (2016).

11) JOGMEC, Trends in the world of mining 2016: Finland (2016)

12) K. Bosecker, FEMS Microbiology reviews, 20, 591 (1997).

13) J. Gentina and F. Acevedo, Minerals, 6, 23 (2016).

14) JETRO, World trade investments report, (2016).

15) JOGMEC, Trends in the world of mining 2015: 
Chile (2015).

16) N. Kamiya, JOGMEC Mineral resources information: Current topics, 18 (2012).

17) USGS, Mineral Commodity Summaries 2017, 54 (2017).

18) J.C. Gentina and F. Acevedo, Electronic Journal of Biotechnology, 16, 16 (2013).

19) C.L. Brierley, Hydrometallurgy, 104, 324 (2010).

20) JX Nippon Mining \& Metals, News release 2014, available at http://www.nmm.jx-group.co.jp/news/

2014/20140827_01_912103.html.

21) JX Nippon Mining \& Metals, News release 2016, available at http://www.nmm.jx-group.co.jp/news/ 2016/post_29.html.

22) OECD, Gross domestic product (GDP) (indicator), doi: 10.1787/dc2f7aec-en.

23) OSF, National Accounts, available at http://www.stat.fi/tup/suoluk/suoluk_kansantalous_ en.html.

24) Mining technology.com, available at http://www.mining-technology.com/projects/talvivaara/.

25) M. Riekkola-Vanhanen, Minerals Engineering, 48, 2 (2013).

26) Talvivaara Mining Company Plc, available at http://www.talvivaara.com/Sustainability.

27) P. Saari and M. Riekkola-Vanhanen, Journal of the Southern African Institute of Mining and Metallurgy, 112, 1013 (2012).

28) P. d'Hugues, P.R. Norris, B. Johnson, A. Grotowski, T. Chmielewski, A. Łuszczkiewic, Z. Sadowski, A. Sklodowska and T. Farbiszewska, Physicochemical Problems of Mineral Processing, 41, 373 (2007).

29) P. d'Hugues, P.R. Norris, K.B. Hallberg, F. Sánchez, J. Langwaldt, A. Grotowski, T. Chmielewski and S. Groudev, Minerals Engineering, 21, 111 (2008). 